\title{
PROTECTIVE EFFECT OF SOME PLANT EXTRACTS ON HYPERURICEMIA IN EXPERIMENTAL ANIMALS
}

\author{
Fatma M. Abo El-Magd`, Tawfik M.F., Moawad F.G. and Ali N.E. \\ Agric. Biochemistry Dept., Fac. of Agric., Ain Shams Univ., P.O. Box 68, Hadayek \\ Shobra 11241, Cairo, Egypt \\ *Corresponding author: Fatma aboelmgd@yahoo.com
}

Received 9 September, 2019

Accepted 16 September, 2019

\section{ABSTRACT}

Hyperuricemia (elevated serum levels of uric acid) is a key risk factor for the development of gout, and has been linked to renal dysfunction, cardiovascular diseases, hypertension, diabetes and metabolic syndrome. Hyperuricemia was induced by oxonic acid (uricase inhibitor) in experimental rats to evaluate the protective effect of alcoholic extracts from parsley shoots, celery seeds and fig leaves. The rats were divided into 6 groups, and the first one served as a normal control group. Three groups of rats were given various plant extracts (celery, parsley and fig) by oral administration using a stomach tube at a dose of $250 \mathrm{mg} / \mathrm{kg}$. A positive control group of rats was administered orally the hypouricemic drug, allopurinol (xanthine oxidase inhibitor) at a dose of $100 \mathrm{mg} / \mathrm{kg}$. A negative control group did not receive any plant extracts or drugs. The various plant extracts and the drug were administered for the rats every day for 9 days. On the $10^{\text {th }}$ day, all groups except the normal control received a single dose of oxonic acid (250 $\mathrm{mg} / \mathrm{kg}$ ) by intraperitoneal injection to induce hyperuricemia. After two hours of hyperuricemia induction by oxonic acid injection, blood samples were collected from all rat groups. The protective effects of various plant extracts were monitored through measurement of uric acid and other blood biochemical analyses for the rats as well as assay of xanthine oxidase enzyme in liver tissues. The data indicated a significant $(P<0.05)$ increase in the levels of uric acid, urea, creatinine and potassium, and a significant $(\mathrm{P}<0.05)$ decrease in the levels of total calcium in serum of hyperuricemic rats (negative control) compared to the normal control group. These results indicated that oxonic acid caused hyperuricemia and renal dysfunction in the nega- tive control group. The protective effects of various plant extracts were established by appearance the levels of uric acid and other kidney function tests near to their normal values which appeared in the normal control group. The different plant extracts exhibited protective effects against hyperuricemia in variant efficacies compared to allopurinol. These efficacies were in the following order: fig > allopurinol $>$ celery $\approx$ parsley. Comparatively, the different plant extracts exhibited inhibitory effects on the activity of liver xanthine oxidase enzyme in variant efficacies compared to allopurinol. These efficacies were in the following order: allopurinol $>$ fig $>$ celery $\approx$ parsley. It can be noticed that fig extract was the most effective treatment against hyperuricemia while allopurinol was the strongest inhibitor against xanthine oxidase activity.

Keywords: Allopurinol, Celery, Fig, Hyperuricemia, Oxonic acid, Parsley, Rats, Uric acid, Xanthine oxidase.

\section{INTRODUCTION}

Uric acid is produced by purine metabolism. When adenine is catabolized, adenosine is converted to inosine, and then to hypoxanthine, which is in turn oxidized by xanthine oxidase (XO) to generate xanthine, and then uric acid. The catabolism of guanine starts with conversion to xanthine and then to uric acid, with the second step also being catalyzed by XO (Cleland et al 1995). In many mammals, uricase converts uric acid into allantoin, which has higher solubility and no obvious adverse effect (Sherman et al 2008). Uric acid is the end product of nucleic acid metabolism in human with the loss of uricase. Uric acid is formed from nucleic acid either endogenously from cell breakdown or exogenously from metabolism of 
food (Choi et al 2005). The amount of urate in the blood depends on the dietary intake of purines, urate biosynthesis, and the rate of urate excretion. Over-production or under-excretion of uric acid leads to hyperuricemia (Wang et al 2008).

Hyperuricemia is a key risk factor for the development of gout, and has been linked to renal dysfunction, cardiovascular diseases, hypertension, diabetes and metabolic syndrome (Choi and Ford, 2007; Johnson et al 2005; Short and Tuttle, 2005). Hyperuricemia is a common metabolic disorder in human. It occurs as a result of overproduction of uric acid and impaired renal uric acid excretion (Terkeltaub, 2003). Increasing in uric acid level also leads to form monosodium urate monohydrate (MSU) crystals in the joints, causing gout, and in the kidney, predisposing to urate nephrolithiasis (Merry et al 2007; Preitner et al 2009). Recently, hyperuricemia linked to cardiovascular diseases (Jin et al 2012).

Gout is one of the most common metabolic disorders with a worldwide distribution and continues to be a major health problem. It affects around $13 \%$ of men and $5 \%$ of the women (Arromede et al 2002). Gout is a metabolic disease caused by long-term purine metabolic disorders and elevated uric acid. Gout is characterized by an excessive concentration of uric acid in the blood, causing the accumulation of monosodium urate crystals in the joints and kidneys leading to acute gouty arthritis and uric acid nephrolithiasis (Kramer and Curhan, 2002).

Xanthine oxidase (XO) is a molybdenumcontaining enzyme, and catalyzes the oxidation of hypoxanthine to xanthine then uric acid (Masuoka et al 2012). Inhibitors of $X O$ are widely used to treat hyperuricemia and gout such as allopurinol (Pacher et al 2006). Allopurinol is a purine selective inhibitor of $\mathrm{XO}$, works by a competitive inhibition mechanism, and blocks the synthesis of uric acid (Riegersperger et al 2011). However, the use of allopurinol can be related to a number of side effects, indicating renal toxicity, even fatal liver necrosis and allergic reactions, such as skin rash. In some cases more severe hypersensitivity reactions may be seen, such as Steven-Johnson Syndrome (Fagugli et al 2008). Febuxostat is also used to treat chronic gout and hyperuricemia. It is a non-purine selective inhibitor of $\mathrm{XO}$, and works by non-competitive inhibition mechanism. Febuxostat is typically only recommended in those who cannot tolerate allopurinol because febuxostat may cause severe side effects such as heart attack. Febuxostat is more effective than standard doses of allopurinol, but not more effective than higher doses of allopurinol (Love et al 2010).

Using of medicinal plants in the treatment of hyperuricemia and gout need to scientific evidences. Several studies are achieved to identify their phytochemicals, that inhibits XO activity and thereby reduce the uric acid levels (Kong et al 2000; Sweeney et al 2001). Flavonoids are widely found in a number of medicinal plants. Some of these flavonoids are found to inhibit XO activities and diminish serum uric acid, which may be new therapeutic agents for hyperuricemia and gout (Lin et al 2002; Mo et al 2007; Van Hoorn et al 2002).

Phytochemical studies on Fig (Ficus carica) fruits and leaves showed that plant contains of numerous bioactive compounds such as phenolic compounds, organic acids, anthocyanin composition, phytosterols, triterpenoids, coumarins, and volatile compounds such as aliphatic alcohols and hydrpcarbons (Gibernau et al 1997; Oliveira et al 2009). Morin and quercetin are major flavonoids found in fig (Ficus carica) fruits and leaves (Kang et al 2004). Leaves, fruits and roots of $F$. carica are used in native medicine in different disorders such as gastro-intestinal, cardiovascular and respiratory disorders. F. carica possess hypolipidemic effect, antioxidant activity, anti-bacterial activity, anti-cancer activity, hypoglycemic activity, anti-fungal activity, anti-pyretic activity, antispasmodic effect and anti-platelet activity, antimutagenic activity (Shuk et al 2013).

Celery seed is used for treating arthritis and gout, and to help reduce muscle spasms, and reduce inflammation (Hanaa et al 2015). Celery extracts inhibited liver XO activity, lowered serum uric acid level, and decreased liver lipid peroxidation in mice treated with oxonic acid. These effects may be due to the presence of several active ingredients in celery leaves and seeds such as furocoumarins (umbelliferone, apigravin \& celerin), flavonoids (apigenin, luteolin \& kaempferol), phenolic compounds (coumaric acid, caffeic acid \& ferulic acid), and tannins. Apigenin decreased serum uric acid and inhibited liver XO activity by $38.4 \%$ in hyperuricemic mice. Concerning the inhibitory actions on liver $\mathrm{XO}$, kaempferol and luteolin were less effective than apigenin (Karim et al 2018).

Parsley shoots contain several active ingredients such as volatile oils, phenols, tannins and flavonoids. Flavones (apigenin and luteolin), and flavonols (kaempferol and quercetin) which occur in glycosidic form, are major flavonoids found in parsley. Parsley is known as one of the antioxidant rich foods that may help in reducing inflammation 
in joints. The leaf part of parsley contains great amount of polyphenols and has been shown to possess high antioxidant activity (Wong and Kitts, 2006; Marín et al 2016). Parsley administration to hyperuricemic rats, lower serum uric acid with the highest reduction from dosage of $7.0 \mathrm{~g} / \mathrm{kg} /$ day compared to $3.5 \mathrm{~g} / \mathrm{kg} /$ day and $10.5 \mathrm{~g} / \mathrm{kg} /$ day. However, $5 \mathrm{mg} / \mathrm{kg} /$ day allopurinol drug was the most effective in reducing serum uric acid level in hyperuricemic rats (Rahmat et al 2018).

Parsley shoots, celery seeds, fig leaves and mulberry twigs are commonly used in Egyptian folk medicine to treat gout and kidney stones. Therefore, the present study was carried out to evaluate the protective effects of flavonoids and other active ingredients extracted from fig leaves, parsley shoots and celery seeds against hyperuricemia induced by injection of rats with oxonic acid. This study was also aimed to compare among the efficacies of these plant extracts and the most common drug in this respect, allopurinol against hyperuricemia in the rats.

\section{MATERIALS AND METHODS}

\section{Materials}

Parsley (Petroselinum crispum) shoots and fig (Ficus carica) leaves were obtained from a local market, Cairo, Egypt. Celery (Apium graveolens) seeds were purchased from Agricultural Seeds, Spices and Medicinal Plants Co., Al-Azhar St., Cairo, Egypt. Oxonic acid and xanthine were purchased from Sigma Chemical Company (St. Louis, Mo). Urea, creatinine, uric acid, potassium and calcium kits were obtained from Egyptian Company for Biotechnology, Obour city, Industrial area, Block 19A, Cairo, Egypt. All other chemicals and solvents used in this work were of analytical grade.

\section{Methods}

\section{Preparation of plant extracts}

Five hundred grams of ground parsley shoots, fig leaves or celery seeds were extracted twice with $2: 1$ of ethanol $(70 \%)$ for 24 hours at room temperature $\left(25^{\circ} \mathrm{C}\right)$, and the samples were filtered after each extraction. Solvent was removed from the combined extracts with a vacuum rotary evaporator at $40^{\circ} \mathrm{C}$ to obtain crude plant extracts. The dried extracts were weighed and stored at $-20^{\circ} \mathrm{C}$ until use (Tsai et al 2004).

\section{Biological evaluation}

\section{Experimental animals}

Thirty male Albino rats of Wistar strain weighing about $100 \mathrm{~g}$ were obtained from the farm of experimental animals in Helwan, Cairo, Egypt. The rats were housed under normal laboratory conditions. The rats had free access food and water ad libitum during the experimental period.

\section{Experimental design}

Rats were randomly divided into 6 groups, and the first one served as a normal control group. Before induction of hyperuricemia, three groups of rats were given various plant extracts (celery, parsley or fig) by oral administration using a stomach tube at a dose of $250 \mathrm{mg} / \mathrm{kg}$. A positive control group of rats was administered orally the hypouricemic drug, allopurinol at a dose of $100 \mathrm{mg} / \mathrm{kg}$. A negative control group did not receive any plant extracts or drugs then it was affected with hyperuricemia. The various plant extracts and the drug were administered for the rats every day for 9 days. On the $10^{\text {th }}$ day, all groups except the normal control received a single dose of oxonic acid (250 $\mathrm{mg} / \mathrm{kg}$ ) by intraperitoneal injection to induce hyperuricemia. After two hours of hyperuricemia induction by oxonic acid injection, blood samples were collected from all rat groups to evaluate the hypouricemic effect of different plant extracts compared to allopurinol (Haidari et al 2008).

\section{Blood sampling and biochemical assays}

Blood samples were collected in clean centrifuge tubes from retro-orbital venous plexus of all animals by using capillary tubes. After that, serum was separated from the collected blood samples by centrifugation and kept in a refrigerator at $4^{\circ} \mathrm{C}$ until analysis. Chemical measurements of Urea (Tietz, 1990), Creatinine (Bowers and Wong, 1980), uric acid (Jung and Parekh, 1970), potassium (Hillman et al 1967) and calcium (Gitelman, 1967) were applied.

\section{Assay of liver xanthine oxidase (XO) activity}

\section{Extraction of xanthine oxidase (XO) from liver}

Rat livers were excised immediately after blood collection, washed in $0.9 \%$ cold saline and rapidly stored at $-80^{\circ} \mathrm{C}$ until further handling. Enzyme extraction has been performed as described by 
Zhu et al (2004). Briefly, livers were homogenized $(10 \% \mathrm{w} / \mathrm{v})$ using $80 \mathrm{mM}$ sodium phosphate buffer $(\mathrm{pH} 7.5)$ and then the homogenate was centrifuged at $5000 \mathrm{~g}$ for $10 \mathrm{~min}$. at $4^{\circ} \mathrm{C}$. Lipid layer was carefully removed, and supernatant was further centrifuged at $5000 \mathrm{~g}$ for $10 \mathrm{~min}$. at $4^{\circ} \mathrm{C}$. The final supernatant was used for enzyme assays.

\section{Determination of xanthine oxidase (XO) activity}

XO activity was assayed by monitoring uric acid formation from xanthine, as described by Hall et al (1990). The reaction mixture contained $1.75 \mathrm{ml}$ of $0.05 \mathrm{M}$ phosphate buffer ( $\mathrm{pH} 7.5), 0.25 \mathrm{ml}$ of liver homogenate and $0.5 \mathrm{ml}$ of $1 \mathrm{mM}$ potassium oxonate to avoid the oxidation of uric acid to allantoin. After preincubation for $15 \mathrm{~min}$ at $37^{\circ} \mathrm{C}$, the reaction was initiated by the addition of $0.5 \mathrm{ml}$ of $250 \mu \mathrm{M}$ xanthine (dissolved in phosphate buffer, $\mathrm{pH}$ 7.5). After $10 \mathrm{~min}$, the reaction was stopped by the addition $0.25 \mathrm{ml}$ of $0.6 \mathrm{M} \mathrm{HCl}$ and the solution was centrifuged at $5000 \mathrm{~g}$ for $5 \mathrm{~min}$. The absorbance of the supernatant was measured at $290 \mathrm{~nm}$ against the blank $(2.25 \mathrm{ml}$ of phosphate buffer, $0.25 \mathrm{ml}$ of liver homogenate, $0.5 \mathrm{ml}$ of potassium oxonate and $0.25 \mathrm{ml}$ of $0.6 \mathrm{M} \mathrm{HCl}$ ). XO activity was expressed as micrograms of uric acid formed per 10 min per milligram protein. The amount of uric acid was calculated by comparing the absorbance with a standard curve of uric acid. Protein concentration was determined by the method of Bradford (1976) using bovine serum albumin as standard.

\section{Statistical analysis}

The data are presented as means \pm SE of three replicates. The recorded data were treated statistically using the one way analysis of variance (ANOVA). The means were compared by Least Significant Difference test (LSD) at $\mathrm{P}<0.05$. Statistical analyses were performed using SPSS statistical software (IBM SPSS Statistics, version 20) (Snedecor and Cochran, 1980).

\section{RESULTS AND DISCUSSION}

Protective effects of alcoholic extracts of fig leaves, parsley shoots and celery seeds against hyperuricemia induced by injection of rats with oxonic acid were monitored through measurement of the levels of uric acid, urea, creatinine, potassium and calcium in serum of rats as well as assay of xanthine oxidase (XO) enzyme in liver tissues. The obtained data were classified into the following items:
1. Effect of parsley, celery and fig extracts on the levels of uric acid in serum of hyperuricemic rats

Table (1) shows the protective effect of alcoholic extracts of parsley, celery and fig on the levels of uric acid in serum of rats affected with hyperuricemia induced by oxonic acid. The data showed a significant $(P<0.05)$ increase in the levels of uric acid $(8.5 \pm 0.28 \mathrm{mg} / \mathrm{dl})$ in serum of rats treated with oxonic acid only (negative control) in comparison with untreated rats (normal control) $(3.2 \pm 0.21 \mathrm{mg} / \mathrm{dl})$. These results indicated that oxonic acid caused hyperuricemia in the negative control group. The protective effects of various plant extracts were established by appearance the levels of uric acid in serum of rats treated with these plant extracts near to its normal value which appeared in the normal control group. The different plant extracts possessed protective effects against hyperuricemia in variant efficacies compared to allopurinol. These efficacies were in the following order: fig > allopurinol > celery $\approx$ parsley. It is evident that fig extract was the most effective treatment against hyperuricemia followed by allopurinol then celery and parsley extracts. The hypouricemic activity of fig extract may be due to the presence of flavonoids such as quercetin and morin (Kang et al 2004) while the hypouricemic activity of parsley and celery extracts may be ascribed to the presence of flavonoids such as apigenin, luteolin, quercetin, myricetin and kaempferol in variant percentages (Wong and Kitts, 2006; Marín et al 2016; Karim et al 2018).

Table 1. Protective effect of alcoholic extracts of parsley, celery and fig on the levels of uric acid in serum of rats treated with oxonic acid

\begin{tabular}{|l|c|}
\hline \multicolumn{1}{|c|}{ Treatments } & Uric acid $(\mathbf{m g} / \mathbf{d l})$ \\
\hline Control & $3.2 \pm 0.21^{\mathrm{d}}$ \\
Oxonic acid (OA) & $8.5 \pm 0.28^{\mathrm{a}}$ \\
Allopurinol + OA & $4.4 \pm 0.23^{\mathrm{c}}$ \\
Fig + OA & $3.2 \pm 0.41^{\mathrm{d}}$ \\
Celery + OA & $5.5 \pm 0.27^{\mathrm{b}}$ \\
Parsley + OA & $5.3 \pm 0.16^{\mathrm{b}}$ \\
\hline
\end{tabular}

The data are presented as means \pm SE calculated from three replicates.

Different letters refer to significant differences at $(P<0.05)$. 


\section{Experimental Animals}

\section{Effect of parsley, celery and fig extracts on the levels of urea and creatinine in serum of hyperuricemic rats}

Table (2) reveals the protective effect of alcoholic extracts of parsley, celery and fig on the levels of urea and creatinine in serum of rats affected with hyperuricemia induced by oxonic acid. The data revealed a significant $(P<0.05)$ increase in the levels of urea $(96.0 \pm 5.7 \mathrm{mg} / \mathrm{dl})$ and creatinine $(1.1$ $\pm 0.03 \mathrm{mg} / \mathrm{dl})$ in serum of rats treated with oxonic acid (negative control) in comparison with untreated rats (normal control) $(42.0 \pm 1.5 \& 0.6 \pm 0.03$ $\mathrm{mg} / \mathrm{dl}$, respectively). This may be attributed to that oxonic acid caused hyperuricemia and consequently renal dysfunction in the negative control group which led to elevation of urea and creatinine levels in serum of rats of this group. The protective effects of various plant extracts were established by appearance the levels of urea and creatinine in serum of rats treated with these plant extracts near to their normal values which appeared in the normal control group.

Table 2. Protective effect of alcoholic extracts of parsley, celery and fig on the levels of urea and creatinine in serum of rats treated with oxonic acid

\begin{tabular}{|l|c|c|}
\hline \multicolumn{1}{|c|}{ Treatments } & $\begin{array}{c}\text { Urea } \\
(\mathbf{m g} / \mathbf{d l})\end{array}$ & $\begin{array}{c}\text { Creatinine } \\
(\mathbf{m g} / \mathbf{d l})\end{array}$ \\
\hline Control & $42.0 \pm 1.5^{\mathrm{d}}$ & $0.6 \pm 0.03^{\mathrm{d}}$ \\
Oxonic acid (OA) & $96.0 \pm 5.7^{\mathrm{a}}$ & $1.1 \pm 0.03^{\mathrm{a}}$ \\
Allopurinol + OA & $61.6 \pm 2.3^{\mathrm{c}}$ & $0.7 \pm 0.05^{\mathrm{c}}$ \\
Fig + OA & $47.3 \pm 1.8^{\mathrm{d}}$ & $0.6 \pm 0.03^{\mathrm{d}}$ \\
Celery + OA & $73.6^{\mathrm{a}} \pm 4.3^{\mathrm{b}}$ & $0.8 \pm 0.04^{\mathrm{b}}$ \\
Parsley +OA & $77.7 \pm 5.5^{\mathrm{b}}$ & $0.8 \pm 0.06^{\mathrm{b}}$ \\
\hline
\end{tabular}

The data are presented as means \pm SE calculated from three replicates.

Different letters refer to significant differences at $(P<0.05)$.

3. Effect of parsley, celery and fig extracts on the levels of potassium and calcium in serum of hyperuricemic rats

Table (3) indicates the protective effect of alcoholic extracts of parsley, celery and fig on the levels of calcium and potassium in serum of rats affected with hyperuricemia induced by oxonic acid. The results indicated a significant $(P<0.05)$ decrease in the levels of calcium $(7.7 \pm 0.15 \mathrm{mg} / \mathrm{dl})$ and a significant $(P<0.05)$ increase in the levels of potassium $(6.5 \pm 0.05 \mathrm{mg} / \mathrm{dl})$ in serum of rats treated with oxonic acid (negative control) in comparison with untreated rats (normal control) $(9.9 \pm 0.18$ \& $5.1 \pm 0.06 \mathrm{mg} / \mathrm{dl}$, respectively). This may be attributed to that oxonic acid caused hyperuricemia and consequently renal dysfunction in the negative control group which led to reduction of calcium levels (hypocalcemia), and elevation of potassium levels (hyperkalemia) in serum of rats of this group. The protective effects of various plant extracts were established by appearance the levels of calcium and potassium in serum of rats treated with these plant extracts near to their normal values which appeared in the normal control group. The kidney function tests (urea, creatinine, calcium and potassium) confirmed that the different plant extracts possessed protective effects against hyperuricemia in the same order of efficacies as previously recorded by measurement of uric acid compared to allopurinol.

Table 3. Protective effect of alcoholic extracts of parsley, celery and fig on the levels of potassium and calcium in serum of rats treated with oxonic acid

\begin{tabular}{|l|l|l|}
\hline \multicolumn{1}{|c|}{ Treatments } & \multicolumn{1}{|c|}{$\begin{array}{c}\text { Calcium } \\
\text { (mg/dl) }\end{array}$} & $\begin{array}{c}\text { Potassium } \\
\text { (mmol/L) }\end{array}$ \\
\hline Control & $9.9 \pm 0.18^{\mathrm{a}}$ & $5.1 \pm 0.06^{\mathrm{d}}$ \\
Oxonic acid (OA) & $7.7 \pm 0.15^{\mathrm{d}}$ & $6.5 \pm 0.05^{\mathrm{a}}$ \\
Allopurinol + OA & $8.9 \pm 0.14^{\mathrm{b}}$ & $5.6 \pm 0.04^{\mathrm{c}}$ \\
Fig + OA & $9.6 \pm 0.12^{\mathrm{a}}$ & $5.3 \pm 0.03^{\mathrm{d}}$ \\
Celery + OA & $8.2 \pm 0.17^{\mathrm{c}}$ & $5.8 \pm 0.06^{\mathrm{b}}$ \\
Parsley + OA & $8.2 \pm 0.16^{\mathrm{c}}$ & $6.0 \pm 0.03^{\mathrm{b}}$ \\
\hline
\end{tabular}

The data are presented as means \pm SE calculated from three replicates.

Different letters refer to significant differences at $(P<0.05)$.

4. Inhibitory effect of parsley, celery and fig extracts on the activity of xanthine oxidase (XO) in liver of hyperuricemic rats

Table (4) illustrates the inhibitory effect of alcoholic extracts of parsley, celery and fig on the activities of xanthine oxidase (XO) enzyme in liver of rats (in vivo) affected with hyperuricemia induced by oxonic acid. The results illustrated a significant $(P<0.05)$ increase in the activities of XO $(0.729 \pm$ $0.007 \mu \mathrm{g}$ uric acid $/ 10 \mathrm{~min} / \mathrm{mg}$ protein) in liver of rats treated with oxonic acid only (negative control) in comparison with untreated rats (normal control) 
$(0.114 \pm 0.003 \mu \mathrm{g}$ uric acid $/ 10 \mathrm{~min} / \mathrm{mg}$ protein $)$. These results are in agreement with those obtained by Huang et al (2008); Raju et al (2012) and Souza et al (2012) who reported that oxonic acid (uricase inhibitor) caused great increases in the activity of $\mathrm{XO}$ in liver of mice treated with this compound in comparison with untreated rats. Obviously, allopurinol exhibited the strongest inhibitory effect on the activity of $\mathrm{XO}$ in liver of rats treated with this compound $(0.191 \pm 0.005 \mu \mathrm{g}$ uric acid/10 $\mathrm{min} / \mathrm{mg}$ protein). Concerning the inhibitory effects of synthetic and natural compounds on XO activity in mouse liver in vivo, Souza et al. (2012) reported that allopurinol recorded high inhibition percentage (85.5\%) while apigenin recoded $38.4 \%$. Comparatively, the different plant extracts exhibited inhibitory effects on the activity of liver xanthine oxidase enzyme in variant efficacies compared to allopurinol. These efficacies were in the following order: allopurinol $>$ fig $>$ celery $\approx$ parsley. Evidently, fig extract was the most effective treatment against hyperuricemia while allopurinol was the strongest inhibitor against xanthine oxidase activity. This may be due to that fig extract possessed a dual action as hypouricemic agent (inhibition of xanthine oxidase which led to decreasing of uric acid synthesis in liver, and inhibition of uric acid reabsorption in kidney which led to increasing of uric acid excretion in urine) while allopurinol possessed the first action only as hypouricemic agent. The hypouricemic activity of fig extract may be due to the presence of flavonoids especially morin. This illustration are supported by $\mathrm{Yu}$ et al. (2006) who reported that morin $\left(3,5,7,2^{\prime}, 4^{`}\right.$-pentahydroxy flavone), which occurs in the twigs of mulberry (Morus alba) exhibits $\mathrm{XO}$ inhibitory activity and also exerts potent inhibitory action on urate uptake in rat renal brushborder membrane vesicles, indicating that this compound acts on the kidney to inhibit urate reabsorption. On the other side, the moderate hypouricemic activity of parsley and celery extracts may be ascribed to the presence of other flavonoids such as apigenin, luteolin, quercetin, myricetin and kaempferol in variant percentages. Our results demonstrated that parsley, celery and especially fig extracts possessed pronounced hypouricemic activity compared to the common hypouricemic drug, allopurinol.
Table 4. Inhibitory effect of alcoholic extracts of parsley, celery and fig on the activity of xanthine oxidase $(\mathrm{XO})$ in liver of rats treated with oxonic acid

\begin{tabular}{|l|c|}
\hline \multicolumn{1}{|c|}{ Treatments } & $\begin{array}{c}\text { Xanthine oxidase }(\mathrm{XO}) \\
\text { activity } \mathbf{\mu g} \text { uric acid } / \mathbf{1 0} \\
\mathbf{m i n} / \mathbf{m g} \text { protein) }\end{array}$ \\
\hline Control & $0.114 \pm 0.003^{\mathrm{e}}$ \\
Oxonic acid (OA) & $0.729 \pm 0.007^{\mathrm{a}}$ \\
Allopurinol + OA & $0.191 \pm 0.005^{\mathrm{d}}$ \\
Fig + OA & $0.404 \pm 0.003^{\mathrm{c}}$ \\
Celery + OA & $0.476 \pm 0.004^{\mathrm{c}}$ \\
Parsley + OA & $0.491 \pm 0.006^{\mathrm{b}}$ \\
\hline
\end{tabular}

The data are presented as means \pm SE calculated from three replicates.

Different letters refer to significant differences at $(P<0.05)$.

\section{REFERENCES}

Arromede E., Michet C.J., Crowson C.S., O'Fallon W.M. and Gabriel S.E. 2002. Epidemiology of gout: is the incidence rising? $\mathbf{J}$. Rheumatol., 29, 2403-2406.

Choi H.K. and Ford E.S. 2007. Prevalence of the metabolic syndrome in individuals with hyperuricemia. American J. of Medicine, 120, 442447.

Choi H.K., Mount D.B. and Reginato A.M. 2005. American College of Physicians; American Physiological Society. Pathogenesis of gout. Ann Intern Med., 143(7), 499-516.

Cleland L.G., Hill C.L. and James M.J. 1995. Diet and arthritis. Bailliere's Clinical Rheumatology, 9, 771-785.

Fagugli R.M., Gentile G., Ferrara G. and Brugnano R. 2008. Acute renal and hepatic failure associated with allopurinol treatment. Clin Nephrol, 70(6), 523-526.

Gibernau M., Buser H.R., Frey J.E. and Hossaert-McKey M. 1997. Volatile compounds from extracts of figs of Ficus carica, Phytochemistry. 46(2), 241-244.

Hanna S.M. Abd El-Rahman and Abd-El Hak A.M. 2015. Xanthine oxidase inhibitory activity and antigout of celery, leek, parsley and molokhia. Advances in Biochemistry. 3(4), 40-50. 
Huang C.G., Shang Y.J., Zhang J., Zhang J.R., Li W.J. and Jiao H. 2008. Hypouricemic effects of phenylpropanoid glycosides acteoside of scrophularia ningpoensis on serum uric acid levels in potassium oxonate-pretreated mice. The American J. of Chinese Medicine. 36(1), 149-157.

Jin M., Yang F., Yang I., Yin Y., Luo J.J. and Wang H. 2012. Uric acid, hyperuricemia and vascular diseases. Front Biosci (Landmark Ed); 17, 656-669.

Johnson R.J., Titte S., Cade J.R., Rideout B.A. and Oliver W.J. 2005. Uric acid, evolution and primitive cultures. Seminars in Nephrology, 25, 3-8.

Kang D.G., Moon M.K., Sohn E.J., Lee D.H. and Lee H.S. 2004. Effects of morin on blood pressure and metabolic changes in fructose induced hypertensive rats. Biol. Pharm Bull 27, 1779-1783.

Karim D., Rakhshandeh H., Golestani M., Forouzanfar F., Sadeghnia R. and Sadeghnia H. 2018. Inhibitory effects of Apium graveolens on xanthine oxidase activity and serum uric acid levels in hyperuricemic mice. Prev Nutr Food Sci. 23(2), 127-133.

Kong L.D., Cai Y., Huang W.W., Cheng C.H. and Tan R.X. 2000. Inhibition of xanthine oxidase by some Chinese medicinal plants used to treat gout. J. of Ethnopharmacology, 73, 199-207.

Kramer H.M. and Curhan G. 2002. The association between gout and nephrolithiasis. Am. J. Kid. Dis., 40, 37-42.

Lin C.M., Chen C.S., Chen C.T., Liang Y.C. and Lin J.K. 2002. Molecular modeling of flavonoids that inhibits xanthine oxidase. Biochemical Biophysical Research Communications, 294, 167-172.

Love B.L., Barrons R. and Veverka A. 2010. Febuxostat for the management of hyperuricemia in people with gout. Pharmacotherapy. 30(6), 594-608.

Masuoka N., Nihei K., Masuoka T., Kuroda K., Sasaki K. and Kubo I. 2012. The inhibition of uric acid formation catalyzed by xanthine oxidase properties of the alkyl caffeates and cardol. J. Food Res., 1(3), 257-262.

Mo S.F., Zhou, F., Lv Y.Z., Hu Q.H., Zhang D.M. and Kong L.D. 2007. Hypouricemic action of selected flavonoids in mice: Structure-activity relationships. Biological \& Pharmaceutical Bulletin, 30, 1551-1556.
Oliveira A.O., Valent̃ao P., Pereira J.A., Silva B.M., Tavares F. and Andrade P.B. 2009. "Ficus carica L.: metabolic and biological screening," Food and Chemical Toxicology. 47(11), 2841-2846.

Pacher P., Nivorozhkin A. and Szabó C. 2006. Therapeutic effects of xanthine oxidase inhibitors: Renaissance half a century after the discovery of allopurinol. Pharmacol Rev., 58(1), 87-114.

Rahmat A., Syafa N., Ahmed S. and Shazini N. 2018. Parsley (Petrolinium crispium) supplementation attenuates serum uric acid level and improves liver and kidney structures in oxonate induced hyperuricemic rats. Oriental Pharmacy and Experimental Medicine, doi.org.10.1007//s 13596-018-0353-7.

Raju R., Joseph S., Cria S., Mathews S. and Umamheshwari M. 2012. Effect of the fractions of Erythrina stricta leaf on serum urate levels and $\mathrm{XO} / \mathrm{XDH}$ activities in oxonateinduced hyperuricemic mice. J. of Applied Pharmaceutical Sci., 2, 89-94.

Ramallo I.A., Zacchino S.A. and Furlan R.L. 2006. A rapid TLC autographic method for the detection of xanthine oxidase inhibitors and superoxide scavengers. Phytochemical Analysis, 17, 15-19.

Riegersperger M., Covic A. and Goldsmith D. 2011. Allopurinol, uric acid, and oxidative stress in cardiorenal disease. International Urology and Nephrology, 43, 441-449.

Sherman M.R., Saifer M.G. and Perez-Ruiz F. 2008. PEG-uricase in the management of treatment-resistant gout and hyperuricemia. Advanced Drug Delivery Reviews, 60, 59-68.

Short R.A. and Tuttle K.R. 2005. Clinical evidence for the influence of uric acid on hypertension, cardiovascular disease, and kidney disease: A statistical modeling perspective. Seminars in Nephrology, 25, 25-31.

Souza R.M., Aparecida de Paula C., Luciane Pereira de Resend M., Grabe Gumaraes A., Dias de Souza Filho J. and Antunes Saude Guimaraes D. 2012. Pharmacological basis for use of lychnophora trichocarpha in gouty arthritis: Anti-hyperuricemic and anti-inflammatory effects of its extracts, fraction and constituents. J. of Ethnopharmacology. 142, 845-850.

Sweeney A.P., Wyllie S.G., Shalliker R.A. and Markham J.L. 2001. Xanthine oxidase inhibitory activity of selected Australian native plants. J. of Ethnopharmacology, 75, 273-277. 
Terkeltaub R.A. 2003. Clinical Practice. Gout. The New England J. of Medicine, 349, 1647-1655. Van Hoorn D.E., Nijveldt R.J., Van Leeuwen P.A., Hofman Z., M'Rabet L., De Bont D.B. and Van Norren K. 2002. Accurate prediction of xanthine oxidase inhibition based on the structure of flavonoids. European J. of Pharmacology, 451, 111-118.

Wallach S.L. 1998. The side effects of allopurinol. Hospital Practice (Minneap), 33, 22.
Wang S.Y., Yang C.W., Liao J.W., Zhen W.W., Chu F.H. and Chang S.T. 2008. Essential oil from leaves of Cinnamomum osmophloeum acts as a xanthine oxidase inhibitor and reduces the serum uric acid levels in oxonateinduced mice. Phytomedicine, 15(11), 940945.

Yu Z., Fong W.P. and Cheng C.H.K. 2006. The dual actions of morin (3,5,7,2,4-Pentahydroxy flavone) as a hypouricemic agent: uricosuric effect and xanthine oxidase inhibitory activity. The J. of Pharmacology and Experimental Therapeutics. 316, 169-175. 


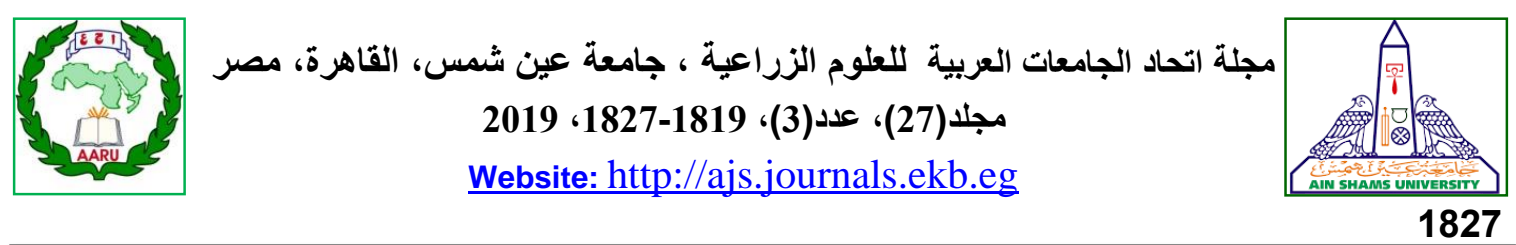

التأثير الوقائى لبعض المستخلصات النباتية على حمض اليوريك المرتفع فى حيوانات التجارب

[145]

$$
\begin{aligned}
& \text { فاطمه محمد أبوالمجد" - مجدى فؤاد توفيق - فاروق جندي معوض - نجاح الشحات على }
\end{aligned}
$$

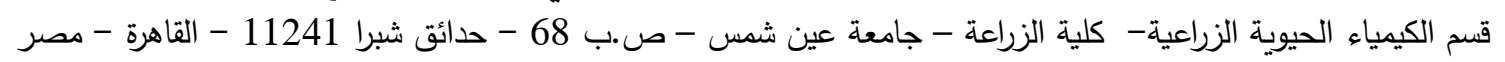

Received 9 September, 2019

Accepted 16 September, 2019

ساعتين فقط من الحقن البريتونى تم سحب عينات الدم

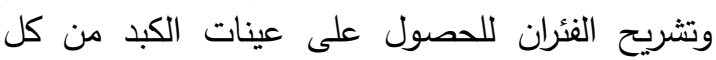

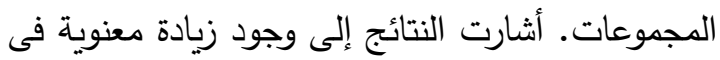

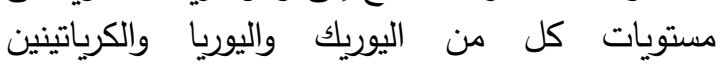
والبوتاسيوم ونقص معنوى في مستوى الكالسيوم الكلى ولى الكين

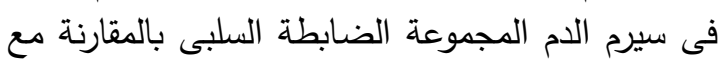
المجموعة الضابطة العادى. أثبتت النتائت النتائج التأثير الوقائى للمستخلصات النباتية المختلفة من خلان النهات ظهور

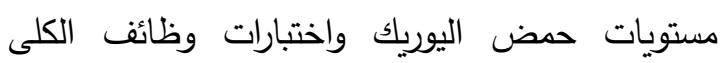

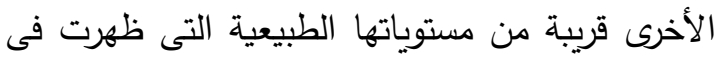
المجموعة الضابطة العادى. ظهرت التأثيرات الوقائية

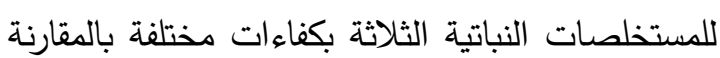

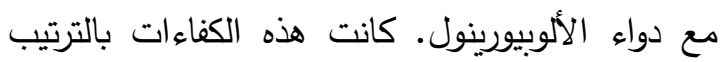

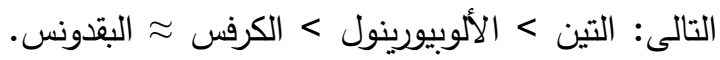

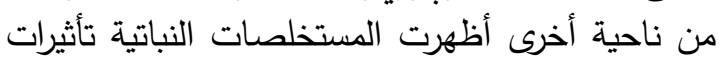

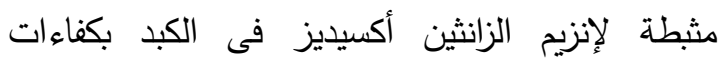

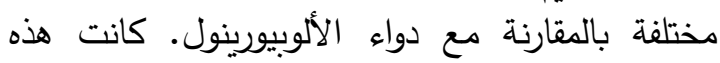

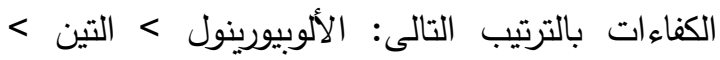
الكرفس ح البقدونس. لوحظ أن مستخلص ألتولئ أوراق التين

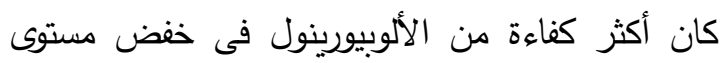

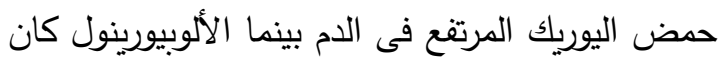

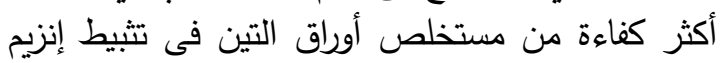
الزانثين أكسيديز فى الكبد.

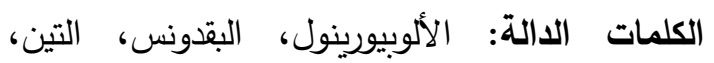

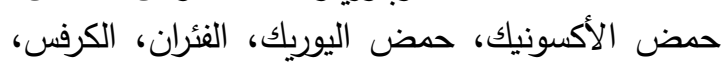
الزانثين أكسيديز الاكيونيز

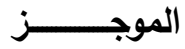

تسبب زيادة حمض اليوريك فى الدم كثير من

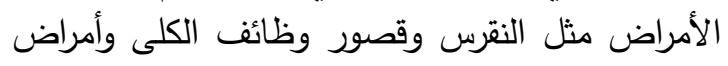

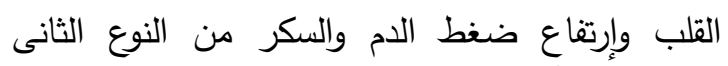

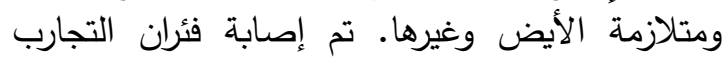

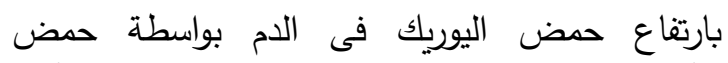
الأكسونيك (مثبط لإنزيم اليوريكيز) وذلك لتثييم التأثير

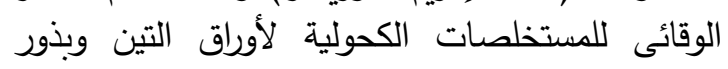
الكرفس ونبات البقدونس. تم تقسيم الفئران إلى لـ 6 مجموعات تغذت على علف قياسى طول فترة التجرية

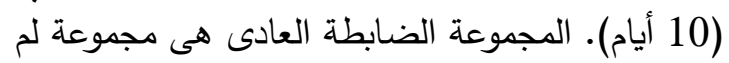

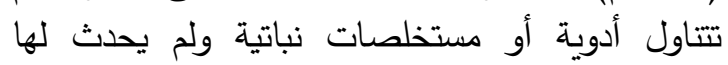

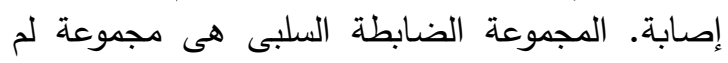
تتناول أدوية أو مستخلصات نباتية وحدث لها إلهابة إلوعابة. المجموعة الضابطة الإيجابى هى مجموعة تم إعطاؤها

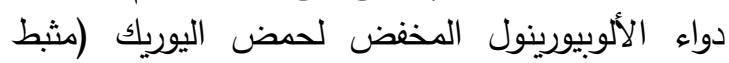
لإنزيم الزانثين أكسيديز) بأنبوبة المعدة بتركيز 100

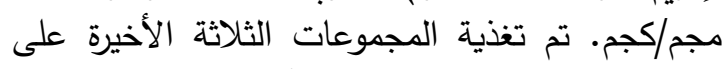
المستخلصات النباتية الثلاثة بأنبوبة المعدة الثبات بتركيز

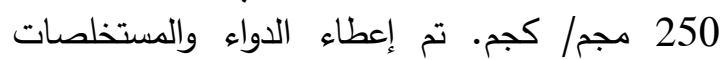
النباتية للفئران بصورة يومية لمدة 9 أيام وفى اليواء اليواء

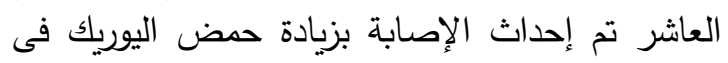

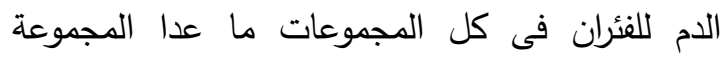
الضابطة العادى بواسطة الحقن البريتونى مرة واحدة التهات

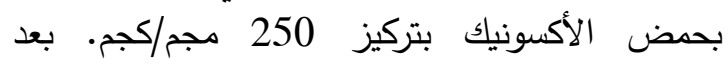

